\title{
IN VITRO ANTHELMINTIC ACTIVITY OF IPOMEA AQUATICA
}

\author{
SRIKANTH I. ", KIRAN KUMAR V., KRISHNA SAI K., SUNITHA M., RAMANJANEYULU K., HIMABINDHU J.
}

Department of Pharmacognosy, Vishnu Institute of Pharmaceutical Education and Research, Narsapur, Medak Email: srikanthinduri313@gmail.com

Received: 22 Jan 2018, Revised and Accepted: 08 Apr 2018

\begin{abstract}
Objective: The present study was aimed at the evaluation of in vitro anthelmintic activity of ethanolic leaf extract of ipomeaaquatica against Indian earthworm Pheretimaposthuma.
\end{abstract}

Methods: Four concentrations ( $25 \mathrm{mg} / \mathrm{ml}, 50 \mathrm{mg} / \mathrm{ml}, 75 \mathrm{mg} / \mathrm{ml}, 100 \mathrm{mg} / \mathrm{ml}$ ) were tested and results were expressed in terms of time for paralysis and time of the death of worms. In this study, Albendazole was used as a standard drug.

Results: Ethanolic leaf extract of ipomea aquatic showed significant activity at higher concentrations when compared to standard group (Albendazole).

Conclusion: It can be concluded that the ethanolic leaf extract of Ipomeaaquaticahas shown more significant anthelmintic activity when compared to Albendazole against Indian earthworm Pheretimaposthuma.

Keywords: Anthelmintic activity, ipomeaaquatica, Albendazole, Ethanolic extract, Pheretimaposthuma

(C) 2018 The Authors. Published by Innovare Academic Sciences Pvt Ltd. This is an open access article under the CC BY license (http://creativecommons.org/licenses/by/4.0/) DOI: http://dx.doi.org/10.22159/ijcpr.2018v10i3.27338

\section{INTRODUCTION}

Helminthic infections are among the commonest infections in man, affecting a large proportion of the world's population. In developing countries they pose a major threat to public health and contribute to the prevalence of malnutrition, anaemia, eosinophilia, and pneumonia. Anthelmintics are drugs that either kill or expel infesting helminths and the gastrointestinal tract is the abode of many helminths, although some also live in tissues, or their larvae migrate into tissues. They harm the host by depriving him of food, causing blood loss, injury to organs, intestinal or lymphatic obstruction and by secreting toxins. Helminthiasis is rarely fatal but is a major cause of morbidity [1].

Helminthiasis is a macro parasitic disease observed in humans and animals in which a part of the body is infested with parasitic worms such as Roundworms (Nematodes), Tapeworms (Cestodes) or Flukes (Trematodes). Typically the worm's reside in the GI Tract. Anthelmintics are drugs that destroy or expel parasitic intestinal worms from the body, byeithervermifuges (stunning) or vermicides (killing). Most of the existing anthelminthics produce side effects such as abdominal pain, loss of appetite, nausea, vomiting, headache and diarrohea. Since ancient times herbal drugs are used for the treatment of parasitic diseases in a human without any side effects. To eradicate the side effects of the present allopathic drugs now scientist are moving towards the herbal drugs what our ancient peoples used [2].

The gastrointestinal helminthes become resistant to currently available anthelmintic drugs, therefore, there is a foremost problem in the treatment of helminthes diseases. Hence there is an increasing demand towards natural anthelmintics [3].

Ipomoea aquatica is a semiaquatic, tropical plant grown as a vegetable for its tender shoots and leaves. It is found throughout the tropical and subtropical regions of the world, although it is not known where it originated. This plant is known in English as water spinach, river spinach, water morning glory, water convolvulus, or by the more ambiguous names Chinese spinach, Chinese Watercress, Chinese convolvulus, swamp cabbage or kangkong in Southeast Asia [4].

Ipomoea aquatica grows in water or on moist soil. Its stems are 2-3 metres (7-10 ft) or longer, rooting at the nodes, and they are hollow and can float. The leaves vary from typically sagittate (arrowhead- shaped) to lanceolate, $5-15 \mathrm{~cm}(2-6 \mathrm{in})$ long and $2-8 \mathrm{~cm}(0.8-3 \mathrm{in})$ broad. The flowers are trumpet-shaped, $3-5 \mathrm{~cm}(1-2 \mathrm{in})$ in diameter, and usually white in colour with a mauve centre. Propagation is either by planting cuttings of the stem shoots that will root along nodes or planting the seeds from flowers that produce seed pods $[5,6]$.

Water spinach, Ipomoea aquaticaForssk. (Convolvulaceae), is an aquatic or semi-aquatic Edible herb [7]. I. aquatica is used traditionally against various disorders like diabetes, liver malfunction, constipation and in the treatment of arsenic and heavy metal poisoning $[7,8]$ Literature reviews revealed the occurrence of significant amounts of phenolic compounds, flavonoids,saponins, $\beta$ carotene and ascorbic acid in I. Aquatica [7]. Genus Ipomoea (Convolvulaceae) are used in traditional system of medicine all over the world and species Ipomoea aquaticaForsk widely used as ailment in the treatment of liver diseases (9) and constipation [10] IA contains several phytoconstituents such as vitamins, including A, B, $\mathrm{C}, \mathrm{E}$, and " $\mathrm{U}$ " (S-methyl methionine) and is used to treat gastric and intestinal Disorders [11].

\section{MATERIALS AND METHODS}

\section{Collection of plant material}

Ipomeaaquatica leaves were collected in the month of August 2017 frommarvellyvillage, vatpallymandal, sangareddy Dist of Telangana, India. The plant was authenticated by D. Venkateshwara Rao, Deputy Director, Telangana. Forest Academy, Dullapally, Hyderabad, Rangareddy District. The fresh leaves were collected, removed all earthy matter, washed, shade, dried and powdered by a pulverizer.

\section{Collection of worms}

Pheritimaposthuma (earthworms) were collected from the manure and identified and washed with water to remove all kinds of dirty water from them.

\section{Chemicals and drugs used \\ Ethanol, Normal saline, Albendazole}

\section{Preparation of plant extract}

The leaves of the plant were dried under shade and crushed in a pulverizer and powdered. The powdered plant extracted with ethanol in Soxhlet apparatus for $72 \mathrm{~h}$ after completion of the 
extraction, the extracts were cooled at room temperature and filtered and evaporated to dryness using rotary evaporator.

\section{Phytochemical screening}

The freshly prepared leaf extract of IAF was qualitatively tested for the presence of chemical constituents. Phytochemical screening of the extract was performed using the following reagents and chemicals: Alkaloids with Mayer's, Hager's and Dragendorffs reagent; Flavonoids with the use of sodium acetate, ferric chloride, amyl alcohol; Phenolic compounds and tannins with lead acetate and gelatin; carbohydrate with Molish's, Fehling's and Benedict's reagent; proteins and amino acids with Millon's, Biuret and xantho protein test. Saponins were tested using hemolysis method; Gum was tested using Molishs reagent and Ruthenium red; Coumarin by $10 \%$ sodium hydroxide and Quinones by Concentrated Sulphuric acid. These were identified by characteristic color changes using standard procedures [12].

These were identified by characteristic colour changes using standard procedures.

The screening results were as follows: Alkaloids +ve; Carbohydrates +ve; Proteins and amino acids +ve; Steroids -ve; Sterols +ve; Phenols +ve; Flavonoids +ve; Gums and mucilage +ve; Glycosides +ve; Saponins -ve; Terpenes +ve and Tannins +ve Where +ve and -ve indicates the presence and absence of compounds.

\section{Preparation of concentrations}

The ethanolic extract of Ipomeaaquatica made into four different concentrations such as $25 \mathrm{mg} / \mathrm{ml}, 50 \mathrm{mg} / \mathrm{ml}, 75 \mathrm{mg} / \mathrm{ml}, 100 \mathrm{mg} / \mathrm{ml}$ by dissolving in normal saline. The standard control group Albendazole was prepared by using $0.5 \% \mathrm{w} / \mathrm{v}$ Carboxy Methyl Cellulose (CMC) as a suspending agent.

\section{Evaluation of anthelmintic activity}

The anthelmintic activity was carried according to the standard method [13-15]. Adult Indian earthworm Pheretimaposthuma has an anatomical and physiological resemblance to the intestinal roundworm parasites of human beings. Indian earthworms were placed in a Petridish containing different concentrations $(25 \mathrm{mg} / \mathrm{ml}$, $50 \mathrm{mg} / \mathrm{ml}, 75 \mathrm{mg} / \mathrm{ml}$, and $100 \mathrm{mg} / \mathrm{ml}$ ) of ethanolic extract of Ipomeaaquatica and standard drug Albendazole. Each Petri dish contains earthworms and observed for time of paralysis as well as time death. Time of paralysis recorded when no movement of any sort could be observed, except when the worm was shaken vigorously as well as the time of death was recorded after ascertaining that worms neither moved when shaken. Finally, the test results were compared with standard reference compound Albendazole.

\section{RESULTS AND DISCUSSION}

Preliminary phytochemical screening of Ipomeaaquatica indicates presence of carbohydrate, alkaloid, flavonoids, proteins and amino acids. ethanolic leaf extract of Ipomeaaquatica shows significant effect on Pheretimaposthuma. Higher concentrations of Ipomea aquatic extracts produce a paralytic effect much earlier and time taken for death was shorter. It shows maximum efficacy at $50 \mathrm{mg} / \mathrm{ml}$ concentration than the standard drug (Albendazole) (table 2).

Table 1: Phytochemical screening of leaves extract of Ipomeaaquatica

\begin{tabular}{lc}
\hline Constituents & Aqueous extract \\
\hline Carbohydrates & + \\
Amino acids & + \\
Glycosides & + \\
Proteins & + \\
Tannins & + \\
Flavonoids & + \\
\hline
\end{tabular}

Table 2: Anthelmintic activity of ethanolic leaf extract of Ipomeaaquatica and standard Albendazole

\begin{tabular}{|c|c|c|c|}
\hline \multirow[t]{2}{*}{ Extract } & \multirow[t]{2}{*}{ Concentrations (mg/ml) } & \multicolumn{2}{|c|}{ Pheretimaposthuma } \\
\hline & & Paralysis(min) & Death(min) \\
\hline \multirow{5}{*}{ Ethanolic extract } & $25 \mathrm{mg} / \mathrm{ml}$ & $21 \pm 1.34$ & $26 \pm 0.18$ \\
\hline & $50 \mathrm{mg} / \mathrm{ml}$ & $17 \pm 0.94$ & $22 \pm 0.62$ \\
\hline & $75 \mathrm{mg} / \mathrm{ml}$ & $16 \pm .09$ & $15 \pm 0.57$ \\
\hline & $100 \mathrm{mg} / \mathrm{ml}$ & $9 \pm 0.61$ & $12 \pm 0.99$ \\
\hline & $25 \mathrm{mg} / \mathrm{ml}$ & $40 \pm 0.43$ & $43 \pm 1.38$ \\
\hline \multirow{3}{*}{ Albendazole } & $50 \mathrm{mg} / \mathrm{ml}$ & $35 \pm 0.60$ & $39 \pm 0.59$ \\
\hline & $75 \mathrm{mg} / \mathrm{ml}$ & $31 \pm 0.81$ & $35 \pm 1.38$ \\
\hline & $100 \mathrm{mg} / \mathrm{ml}$ & $22 \pm 1.4$ & $25 \pm 0.92$ \\
\hline
\end{tabular}

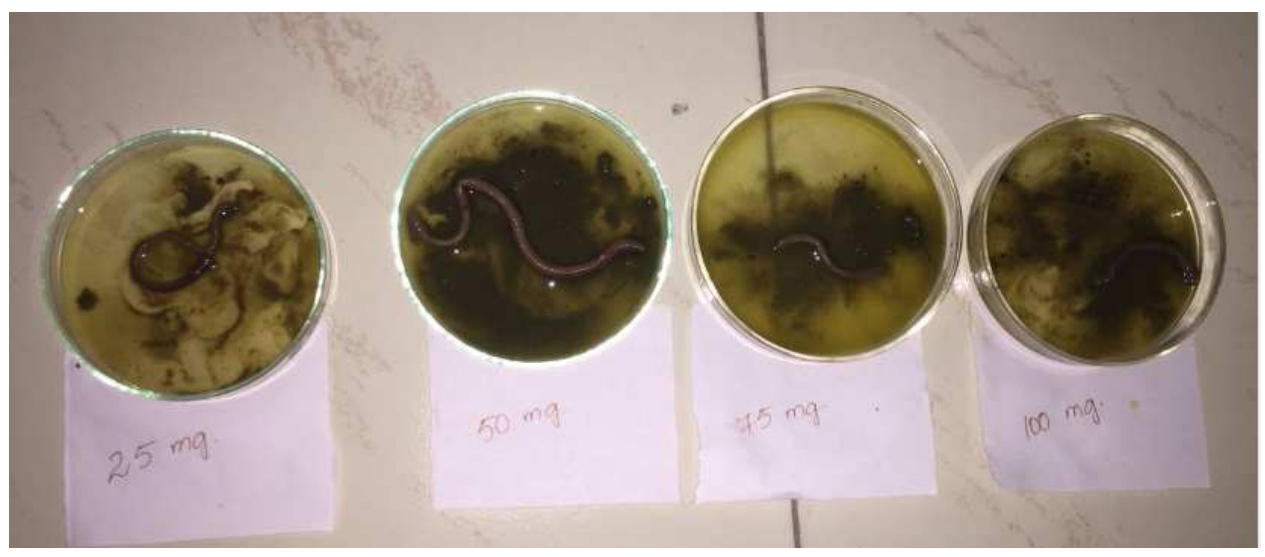

Fig. 1: In vitro experimental model setup to evaluate the antihelmintic activity 


\section{CONCLUSION}

It can be concluded that the ethanolic leaf extract of Ipomeaaquaticahas shown more significant anthelmintic activity when compared to Albendazole against Indian earthworm Pheretimaposthuma.

\section{ACKNOWLEDGEMENT}

We sincerely thankful to our principal Dr. A. Ramesh and staff members, Director and chairman of our college Vishnu Institute of Pharmaceutical Education and Research (VIPER) for supporting us.

\section{AUTHORS CONTRIBUTIONS}

All the author have contributed equally

\section{CONFLICT OF INTERESTS}

Declared none

\section{REFERENCES}

1. Bundy DA. Immunoepidemiology of intestinal helmintic infection I: The global burden of intestinal nematode disease. Trans R Soc Trop Med Hyg 1994;8:259-61.

2. Rafi Khan P. Anthelmintic activity of nerium oleander flower extract in Indian adult earthworm. J Natural Product Plant Resources 2011;1:40-6.

3. Sondhi SM, Shahu R, Magan Archana. Anthelmintic activity of platycladusorientalis leaves extract. Indian Drugs 1994;31:317-20.

4. Kangkong/Ipomoea aquatica Forsk./POTATO VINE/Herbal Medicinal Therapies/Philippine Alternative Medicine". Stuartxchange.org; 2014.
5. Growing kangkong in water. curiousgardener.com. [Last accessed on 10 Dec 2017]

6. Kangkungking.com. Kangkungking.com. [Last accessed on 20 Nov 2012].

7. Dua TK, Dewanjee S, Gangopadhyay M, Khanra R, Zia-Ul-Haq M, De Feo V. Ameliorative effect of water spinach, Ipomoea aquatic (Convolvulaceae), against experimentally induced arsenic toxicity. JTransl Med. 2015;13:81.

8. Chopra RN, Nayar SL, Chopra IC. Glossary of Indian medicinal plants. New Delhi, India: Council of Scientific and Industrial Research; 1956.

9. Badruzzaman SM, Husain W. Some aquatic and marshy land medicinal plants from Hardoi district of Uttar Pradesh. Fitoterapia 1992;63:245-7.

10. Samuelsson G, Farah $\mathrm{MH}$, Claeson $\mathrm{P}$, Hagos $\mathrm{M}$, Thulin $\mathrm{M}$, Hedberg 0 , et al. Inventory of plants used in traditional medicine in somalia II. Plants of the families Combretaceae to Labiatae. J Ethnopharmacol 1992;37:47-70.

11. Cornelius J, Nugteren JA, Westphal E. Kang-kong (Ipomoea aquaticaForssk). An important leaf vegetable in Southeastern Asia. Abstracts Trop Agric 1985;10:9-21.

12. Trease GE, Evans WC. Pharmacognosy, London. ELBS 1989;223:246-9.

13. T Ghosh, TK Maity, Bose A, Dash GK. Indian Journal of Natural Product; 2009. p. 16-9.

14. Adnaik RS, Bhagwat DA, Raut ID, Mohite SK, Magdum CS. Laxative and anthelmintic potential of Cassia alata flower extract. Res J Pharm Technol 2011;4:98-100.

15. Kane SR, Adnaik RS, Apte VA, Magdum CS. In vitro anthelmintic activity of senna occidentalis. Res J Pharmacognosy Phyto Chem 2017;2:182-4. 